\title{
Molecular Analysis of Forensically Important Blow Flies in Thailand
}

\author{
Narin Sontigun ${ }^{1}$, Kabkaew L. Sukontason ${ }^{1}$, Jens Amendt ${ }^{2}$, Barbara K. Zajac ${ }^{3}$, Richard Zehner ${ }^{2}$, \\ Kom Sukontason ${ }^{1}$, Theeraphap Chareonviriyaphap ${ }^{4}$ and Anchalee Wannasan ${ }^{1, *}$ \\ 1 Department of Parasitology, Faculty of Medicine, Chiang Mai University, Chiang Mai 50200, Thailand; \\ narinsontigun@gmail.com (N.S.); kabkaew.s@cmu.ac.th (K.L.S.); kom.s@cmu.ac.th (K.S.) \\ 2 Institute of Legal Medicine, Forensic Biology/Entomology, Kennedyallee 104, \\ Frankfurt am Main 60596, Germany; amendt@em.uni-frankfurt.de (J.A.); zehner@em.uni-frankfurt.de (R.Z.) \\ 3 Department for Forensic Genetics, Institute of Forensic Medicine and Traffic Medicine, Voßstraße 2, \\ Heidelberg 69115, Germany; barbarakarolina.zajac@med.uni-heidelberg.de \\ 4 Department of Entomology, Faculty of Agriculture, Kasetsart University, Bangkok 10900, Thailand; \\ faasthc@ku.ac.th \\ * Correspondence: kdantra@gmail.com; Tel.: +66-8-9434-6851
}

Received: 13 September 2018; Accepted: 6 November 2018; Published: 8 November 2018

\begin{abstract}
Blow flies are the first insect group to colonize on a dead body and thus correct species identification is a crucial step in forensic investigations for estimating the minimum postmortem interval, as developmental times are species-specific. Due to the difficulty of traditional morphology-based identification such as the morphological similarity of closely related species and uncovered taxonomic keys for all developmental stages, DNA-based identification has been increasing in interest, especially in high biodiversity areas such as Thailand. In this study, the effectiveness of long mitochondrial cytochrome $c$ oxidase subunit I and II (COI and COII) sequences (1247 and $635 \mathrm{bp}$, respectively) in identifying 16 species of forensically relevant blow flies in Thailand (Chrysomya bezziana, Chrysomya chani, Chrysomya megacephala, Chrysomya nigripes, Chrysomya pinguis, Chrysomya rufifacies, Chrysomya thanomthini, Chrysomya villeneuvi, Lucilia cuprina, Lucilia papuensis, Lucilia porphyrina, Lucilia sinensis, Hemipyrellia ligurriens, Hemipyrellia pulchra, Hypopygiopsis infumata, and Hypopygiopsis tumrasvini) was assessed using distance-based (Kimura two-parameter distances based on Best Match, Best Close Match, and All Species Barcodes criteria) and tree-based (grouping taxa by sequence similarity in the neighbor-joining tree) methods. Analyses of the obtained sequence data demonstrated that $\mathrm{COI}$ and COII genes were effective markers for accurate species identification of the Thai blow flies. This study has not only demonstrated the genetic diversity of Thai blow flies, but also provided a reliable DNA reference database for further use in forensic entomology within the country and other regions where these species exist.
\end{abstract}

Keywords: forensic entomology; molecular identification; COI; COII; blow flies; Thailand

\section{Introduction}

Among necrophagous insects, blow flies (Diptera: Calliphoridae) are the first comers to colonize on a corpse within a few hours after death [1-3]. Therefore, the age of developing blow flies on a corpse can be used to estimate a minimum postmortem interval $\left(\mathrm{PMI}_{\mathrm{min}}\right)$, which is the window of time between the day when insects first colonized the body and when the corpse is found [4]. Since developmental times of blow flies are species-specific even between closely related species, correct species identification is a crucial step for accurate $\mathrm{PMI}_{\min }$ estimation [5]. Traditionally, blow flies would be identified using morphology, but the available taxonomic keys do not provide features for all 
developmental stages (e.g., immature stages), and the lack of important morphological characteristics in partial or damaged specimens makes morphological identification difficult. DNA-based identification has been intensively carried out for forensically important blow flies [6-8]. Additionally, the obtained DNA sequences can provide an estimate of evolutionary history and relationships among organisms via phylogenetic analysis [9-11]. Regions of mitochondrial DNA (mtDNA) and nuclear DNA (nuDNA) are widely used for molecular-based discrimination between species. However, the advantageous features of mtDNA (i.e., high copy number per cell, high rate of nucleotide substitutions, and haploid maternal inheritance) make them more ideal for species identification [12]. Among mtDNA, the cytochrome $c$ oxidase subunit I and II (COI and COII) genes have been generally used for species discrimination as well as evolutionary relationship studies because they have a high rate of genetic variation [7,8,13-17].

In Thailand, a total of 93 blow fly species belonging to nine subfamilies and 27 genera have been recognized [18]. In particular, genera Chrysomya Robineau-Desvoidy, Lucilia Robineau-Desvoidy, Hemipyrellia Townsend, and Hypopygiopsis Townsend are often present in carrion fly surveys in the country [19-22]. In addition, 10 species were reported from human corpses as forensically important blow fly evidence, i.e., Chrysomya megacephala (Fabricius), Chrysomya rufifacies (Macquart), Chrysomya villeneuvi Patton, Chrysomya nigripes Aubertin, Chrysomya bezziana Villeneuve, Chrysomya chani Kurahashi, Chrysomya pinguis (Walker), Lucilia cuprina (Wiedemann), Lucilia porphyrina (Walker), and Hemipyrellia ligurriens (Wiedemann) [23-25]. So far, blow flies in Thailand have been primarily identified based on available taxonomic keys which cannot permit identification of all life stages [18,25-27]. Recently, difficulties in morphology-based identification have been solved by using the molecular approach. In 2010, partial sequences of COI and COII (1324 bp) were used for the species identification of three forensically important blow fly species, C. megacephala, C. rufifacies, and L. cuprina, from field work in six provinces of Thailand [28]. In 2016, the discrimination of 13 species of forensically relevant flies (nine species of blow flies and four species of flesh flies) from northern Thailand was achieved using nuclear $28 \mathrm{~S}$ rRNA ( $1000 \mathrm{bp})$ and mitochondrial COI ( 700 bp) genes [6]. The immature stages of $C$. villeneuvi, C. pinguis, and L. porphyrina from human corpses in Chiang Mai province were also identified using morphology and COI analyses (1247 bp), and the two latter blow flies have subsequently been included as flies of forensic importance in Thailand [24]. Apart from those publications, genetic data related to forensic entomology in Thailand are still scarce. Thus, it is necessary to establish a reliable local DNA reference database for rapid and accurate species identification. Hence, the aim of this study was to generate nearly full lengths of the COI and COII sequences of 16 forensically important Thai blow fly species and then evaluate the effectiveness of both genes for accurate species identification.

\section{Materials and Methods}

\subsection{Specimen Collection}

The total of 113 adult blow fly specimens used in this study were obtained from one of three ways: field collections, laboratory colony, and myiasis case (Supplementary Table S1). Firstly, 106 blow flies were collected from various field areas in six provinces of Thailand during March 2013 to March 2015 (Supplementary Figure S1). Briefly, the flies were attracted with $300 \mathrm{~g}$ of 1-day-tainted beef offal and were caught using either the semi-automatic funnel trap [22] or a sweep net. The specimens from the field collection were sacrificed by (1) spraying them with and then keeping them in $85 \%$ ethanol; (2) placing them in each test tube and then keeping in a freezer box; and (3) keeping them alive before transporting them back to the laboratory for sacrificing by freezing at $-20{ }^{\circ} \mathrm{C}$ for $2 \mathrm{~h}$. All of the specimens were morphologically identified using the taxonomic key of Kurahashi and Bunchu [18] and subsequently preserved in either $85 \%$ ethanol or kept as dried specimens until they were used for molecular analysis. Secondly, six specimens of blow flies were obtained from the laboratory colony of the Department of Parasitology, the Faculty of Medicine, Chiang Mai University (Supplementary Table S1). Lastly, a C. bezziana maggot that was received from the ocular myiasis of a 
patient admitted to Maharaj Nakorn Chiang Mai Hospital in October 2014 was reared into an adult (Supplementary Table S1). In addition, two adult house flies, Musca domestica Linnaeus, were obtained from the same rearing laboratory and used as an outgroup.

\subsection{DNA Extraction, Amplification, and Sequencing}

Following the manufacturer's protocol, genomic DNA was extracted from one or two legs of each fly using the Phire Animal Tissue Direct PCR Kit (Thermo Scientific, Waltham, MA, USA). The remaining parts of the fly were kept as voucher specimens at the Fly Research Unit, the Department of Parasitology, the Faculty of Medicine, Chiang Mai University.

DNA amplification was carried out according to the manufacturer's protocol for using the Phire Animal Tissue Direct PCR Kit (Thermo Scientific, Waltham, MA, USA). Partial COI sequences were amplified using the primers TY-J-1460 (5'-TACAATTTATCGCCTAAACTTCAGCC-3') and C1-N-2800 (5'-CATTTCAAGCTGTGTAAGCATC-3') [13], while the primers C2-J-3138 (5'-AGAGCCTCTC CTTTAATAGAACA-3') [29] and TK-N-3775 (5'-GAGACCATTACTTGCTTTCAGTCATCT-3') [30] were used for amplification of partial COII sequences. The cycling conditions consisted of an initial denaturation step at $98{ }^{\circ} \mathrm{C}$ for $5 \mathrm{~min}$ followed by 40 cycles of denaturation at $98^{\circ} \mathrm{C}$ for $5 \mathrm{~s}$, annealing at $61.7{ }^{\circ} \mathrm{C}$ (for $\mathrm{COI}$ ) or $45^{\circ} \mathrm{C}$ (for $\mathrm{COII}$ ) for $5 \mathrm{~s}$, extension at $72{ }^{\circ} \mathrm{C}$ for $30 \mathrm{~s}$, and a final extension at $72{ }^{\circ} \mathrm{C}$ for $1 \mathrm{~min}$. The amplified PCR products were electrophoretically separated on $1 \%$ agarose gel, stained with RedSafe ${ }^{\mathrm{TM}}$ Nucleic Acid Staining Solution $(20,000 \times)$ (iNtRon BiotechnologySeongnam-si, South Korea), and visualized under UV light. The PCR products were purified using QIAquick ${ }^{\circledR}$ PCR Purification Kit (QIAGEN, Hilden, Germany) according to the manufacturer's instructions and subsequently sent to First BASE Laboratories Sdn. Bhd. (Selangor, Malaysia) for Sanger sequencing. The purified PCR products were bidirectionally sequenced with the BigDye ${ }^{\circledR}$ Terminator v3.1 Cycle Sequencing Kit (Applied Biosystems, Foster City, CA, USA) by using the same primers as used in the PCR.

\subsection{DNA Sequence Alignment and Sequence Analysis}

For both COI and COII, the obtained sequences were manually edited and assembled into the complete bidirectional consensus sequences using BioEdit software version 7.0.9.0. [31]. Within the same species, the number of polymorphic sites and haplotypes for both genes (COI and COII) were evaluated by DnaSP software version 5.10.01 [32]. The genetic variation within (intraspecific) and between (interspecific) species was calculated using the Kimura two-parameter (K2P) model [33] in MEGA6 software [34]. Furthermore, the frequency distribution of the intra- and interspecific K2P distances was plotted for each gene to observe the overlap in genetic variability.

\subsection{Nucleotide Sequence Accession Numbers}

A representative sequence of identical conspecific haplotypes isolated from the specimens collected from the same area and province were deposited in GenBank; 90 COI and 67 COII representative sequences of blow flies were assigned accession numbers as KR921597-KR921686 and KU556169-KU556235 (Supplementary Tables S2 and S3), respectively. Notably, this study was the first to add COI sequences for L. sinensis and H. tumrasvini and COII sequences for C. chani, C. thanomthini, L. sinensis, and H. tumrasvini into GenBank.

\subsection{DNA Marker Assessments (COI and COII) for Species Identification}

\subsubsection{Distance-Based Analysis}

Distance-based identification of specimens was performed using SpeciesIdentifier software version 1.8 [35] based on the K2P distance. The percentage of correctly identified specimens of each gene was estimated using the Best Match (BM), Best Close Match (BCM) and All Species Barcodes (ASB) criteria as described by Meier et al. [35]. It is important to note that a sequence without a conspecific match in the 
dataset will be assigned as incorrect identification. Thus, a sequence of $C$. bezziana was duplicated before analysis. This brought the total of analyses to 114 COI and 101 COII sequences.

\subsubsection{Tree-Based Analysis}

The neighbor-joining (NJ) tree was used to identify species using the criteria of Hebert et al. [36]. NJ trees of both genes (COI and COII) were constructed using the K2P model [33] and tested using 1000 bootstrap replications in MEGA6 software [34]. Musca domestica was used as an outgroup in all analyses.

\section{Results}

\subsection{Sequence Analysis}

The partial COI amplicons (1247 bp) of 113 blow fly specimens were all successfully sequenced (Supplementary Table S1). The alignments of these 113 COI blow fly sequences revealed 300 variable sites and 284 parsimony informative sites with no indels. The average $\mathrm{A}+\mathrm{T}$ content from all blow fly sequences was $69.5 \%(\mathrm{~A}=30.7 \%$ and $\mathrm{T}=38.8 \%)$, while the average $\mathrm{G}+\mathrm{C}$ content was $30.5 \%(\mathrm{C}=14.9 \%$ and $G=15.6 \%)$. When excluding the species represented by a single sequence (C. bezziana), the number of polymorphic sites within a species ranged from 1 (C. thanomthini) to 31 (L. cuprina), and the number of haplotypes within a species ranged from 2 (C. thanomthini and H. tumrasvini) to 7 (C. pinguis) (Table 1 and Supplementary Table S2).

Table 1. Percentage of mean intraspecific Kimura two-parameter (K2P) distances of Thai blow flies based on 1247 bp of COI sequences. The number of sequences, polymorphic sites, and haplotypes are shown.

\begin{tabular}{ccccc}
\hline Species & No. of Sequences & No. of Polymorphic Sites & No. of Haplotypes & Intraspecific Divergence (Minimum-Maximum) \\
\hline C. bezziana & 1 & N/A & 1 & N/A \\
C. megacephala & 15 & 8 & 4 & $0.1(0.0-0.6)$ \\
C. chani & 8 & 6 & 5 & $0.1(0.0-0.4)$ \\
C. pinguis & 7 & 14 & 7 & $0.4(0.2-0.6)$ \\
C. thanomthini & 2 & 1 & 2 & 0.1 \\
C. nigripes & 4 & 4 & 4 & $0.2(0.1-0.2)$ \\
C. rufifacies & 14 & 5 & 6 & $0.1(0.0-0.2)$ \\
C. villeneuvi & 14 & 8 & 6 & $0.1(0.0-0.4)$ \\
L. cuprina & 8 & 31 & 5 & $0.7(0.0-2.4)$ \\
L. papuensis & 9 & 12 & 5 & $0.5(0.0-0.8)$ \\
L. porphyrina & 6 & 23 & 6 & $0.7(0.2-1.1)$ \\
L. sinensis & 5 & 11 & 6 & $0.4(0.0-0.8)$ \\
H. igurriens & 10 & 6 & 4 & $0.1(0.0-0.4)$ \\
H. pulchra & 4 & 6 & 3 & $0.3(0.2-0.4)$ \\
H. infumata & 3 & 4 & 2 & $0.2(0.2-0.3)$ \\
H. tumrasvini & 3 & 2 & $0.1(0.0-0.2)$ \\
\hline
\end{tabular}

N/A, species represented by only one specimen; therefore, polymorphic site and intraspecific distance could not be calculated.

Of 113 blow fly specimens, the partial COII amplicons ( $635 \mathrm{bp}$ ) of 110 blow fly specimens were successfully sequenced (Supplementary Table S1). However, 10 sequences of all H. ligurriens specimens showed a $30 \mathrm{bp}$ deletion in the multiple alignment. Thus, the sequences of $H$. ligurriens were tested for pseudogenes by protein translation using the invertebrate mitochondrial codes in MEGA6 software [34]. As stop codons appeared after the deletion, it was assumed that nuclear mitochondrial DNA insertions (NUMTs) were amplified instead of the target gene. Therefore, all H. ligurriens sequences were omitted from the analysis. The multiple alignment of the 100 blow fly sequences showed 154 variable sites and 148 parsimony informative sites. The average $\mathrm{A}+\mathrm{T}$ content from all blow fly sequences was $73.3 \%$ $(\mathrm{A}=33.3 \%$ and $\mathrm{T}=40.0 \%)$, while the average $\mathrm{G}+\mathrm{C}$ content was $26.7 \%(\mathrm{C}=14.2 \%$ and $\mathrm{G}=12.5 \%)$. When excluding species represented by a single sequence (C. bezziana), the number of polymorphic sites within a species varied from 0 (C. megacephala and C. chani) to 14 (L. porphyrina), and the number of haplotypes within a species varied from 1 (C. megacephala and C. chani) to 5 (L. porphyrina) (Table 2 and Supplementary Table S3). 
Table 2. Percentage of mean intraspecific Kimura two-parameter (K2P) distances of Thai blow flies based on $635 \mathrm{bp}$ of COII sequences. The number of sequences, polymorphic sites, and haplotypes are shown.

\begin{tabular}{ccccc}
\hline Species & No. of Sequences & No. of Polymorphic Sites & No. of Haplotypes & Intraspecific Divergence (Minimum-Maximum) \\
\hline C. bezziana & 1 & N/A & 1 & N/A \\
C. megacephala & 13 & 0 & 1 & 0.0 \\
C. chani & 8 & 0 & 1 & 0.0 \\
C. pinguis & 7 & 3 & 4 & $0.2(0.0-0.3)$ \\
C. thanomthini & 2 & 1 & 2 & 0.2 \\
C. nigripes & 3 & 4 & 3 & $0.4(0.3-0.6)$ \\
Crufifacies & 14 & 4 & 4 & $0.1(0.0-0.5)$ \\
C. villeneuvi & 14 & 2 & 2 & $0.1(0.0-0.3)$ \\
L. cuprina & 8 & 1 & 3 & $0.0(0.0-0.2)$ \\
L. papuensis & 9 & 5 & 5 & $0.4(0.0-0.8)$ \\
L. porphyrina & 6 & 14 & 3 & $0.8(0.0-1.9)$ \\
L. sinensis & 5 & 5 & 3 & $0.3(0.0-0.8)$ \\
H. pulchra & 4 & 2 & 2 & $0.2(0.0-0.3)$ \\
H. infumata & 3 & 1 & 2 & $0.1(0.0-0.2)$ \\
H. tumrasvini & 3 & 1 & $0.1(0.0-0.2)$ \\
\hline
\end{tabular}

$\mathrm{N} / \mathrm{A}$, species represented by only one specimen; therefore, polymorphic site and intraspecific distance could not be calculated.

\subsection{Genetic Variation}

Based on $1247 \mathrm{bp}$ of COI sequences, the mean intraspecific K2P distances of blow flies ranged from 0.1 to $0.7 \%$ (Table 1) while the mean interspecific K2P distances ranged from $1.1 \%$ (H. ligurriens/H. pulchra) to $11.1 \%$ (C. bezziana/L. porphyrina) (Table 3). The mean interspecific K2P distances within Chrysomyinae varied from 2.6\% (C. megacephala/C. pinguis) to $8.1 \%$ (C. bezziana/C. rufifacies) whereas within Luciliinae, it ranged from $1.1 \%$ (H. ligurriens/H. pulchra) to $9.0 \%$ (L. papuensis/H. infumata and L. porphyrina/H. infumata). Between subfamilies, the mean interspecific K2P distances ranged from $7.9 \%$ (C. chani/L. cuprina) to $11.1 \%$ (C. bezziana/L. porphyrina). However, a small overlap $(1.4 \%$ from $1.0 \%$ to $2.4 \%$ ) was observed between intra- and interspecific K2P distances (Figure 1).

Based on $635 \mathrm{bp}$ of COII sequences, the mean intraspecific K2P distances of blow flies ranged from 0.0 to $0.8 \%$ (Table 2), while the mean interspecific K2P distances varied from $1.8 \%$ (C. megacephala/C. pinguis) to $11.6 \%$ (C. nigripes/L. papuensis) (Table 3). Within Chrysomyinae, the divergence varied from $1.8 \%$ (C. megacephala/C. pinguis) to $7.2 \%$ (C. pinguis/C. villeneuvi), whereas the divergence within Luciliinae ranged from $4.2 \%$ (H. pulchra/H. infumata) to $9.9 \%$ (L. papuensis/H. infumata). The mean interspecific K2P distances between subfamilies ranged from $7.0 \%$ (C. chani/H. tumrasvini) to $11.6 \%$ (C. nigripes/L. papuensis). However, a small overlap $(0.1 \%$ from $1.8 \%$ to $1.9 \%$ ) was observed between intra- and interspecific K2P distances (Figure 2). 
Table 3. Percentage of mean interspecific K2P distances of Thai blow flies based on 1247 bp of COI (bold) and 635 bp of COII (narrow) sequences.

\begin{tabular}{|c|c|c|c|c|c|c|c|c|c|c|c|c|c|c|c|c|c|}
\hline \multirow{2}{*}{ No. } & \multirow{2}{*}{ Species } & \multicolumn{16}{|c|}{ Interspecific Distance } \\
\hline & & 1 & 2 & 3 & 4 & 5 & 6 & 7 & 8 & 9 & 10 & 11 & 12 & 13 & 14 & 15 & 16 \\
\hline 1 & C. bezziana & - & 3.6 & 5.1 & 3.8 & 3.3 & 5.0 & 6.3 & 6.6 & 9.2 & 10.9 & 9.6 & 11.1 & - & 9.4 & 10.0 & 9.4 \\
\hline 2 & C. megacephala & 4.9 & - & 4.4 & 1.8 & 2.2 & 5.3 & 6.4 & 6.3 & 9.6 & 10.6 & 9.3 & 11.2 & - & 10.1 & 10.8 & 8.5 \\
\hline 3 & C. chani & 5.6 & 4.5 & - & 3.9 & 4.8 & 5.3 & 5.8 & 6.5 & 8.9 & 10.0 & 9.7 & 10.7 & - & 7.6 & 8.6 & 7.0 \\
\hline 4 & C. pinguis & 5.4 & 2.6 & 4.3 & - & 2.5 & 5.5 & 6.9 & 7.2 & 8.7 & 10.6 & 8.7 & 11.1 & - & 8.9 & 10.0 & 8.4 \\
\hline 5 & C. thanomthini & 5.6 & 3.4 & 4.5 & 2.8 & - & 6.1 & 6.6 & 6.9 & 9.7 & 10.9 & 9.4 & 11.3 & - & 9.6 & 10.9 & 9.3 \\
\hline 6 & C. nigripes & 6.6 & 5.4 & 5.9 & 6.2 & 6.2 & - & 6.3 & 6.3 & 10.0 & 11.6 & 10.5 & 11.4 & - & 8.4 & 10.1 & 9.1 \\
\hline 7 & C. rufifacies & 8.1 & 7.0 & 6.8 & 7.9 & 7.9 & 7.9 & - & 3.4 & 9.6 & 10.3 & 9.3 & 10.5 & - & 8.4 & 9.7 & 8.3 \\
\hline 8 & C. villeneuvi & 7.6 & 6.7 & 7.4 & 7.8 & 7.5 & 7.7 & 4.7 & - & 9.6 & 10.8 & 9.5 & 9.9 & - & 8.7 & 9.7 & 8.8 \\
\hline 9 & L. cuprina & 9.6 & 8.8 & 7.9 & 9.6 & 9.0 & 9.7 & 10.3 & 10.1 & - & 9.4 & 5.7 & 7.0 & - & 5.7 & 6.3 & 4.8 \\
\hline 10 & L. papuensis & 10.5 & 10.7 & 8.3 & 10.7 & 10.1 & 9.9 & 10.7 & 10.0 & 6.7 & - & 8.7 & 6.0 & - & 9.6 & 9.9 & 7.5 \\
\hline 11 & L. porphyrina & 11.1 & 10.2 & 9.2 & 10.4 & 9.8 & 11.0 & 10.7 & 10.4 & 6.2 & 7.8 & - & 8.0 & - & 7.4 & 7.1 & 6.3 \\
\hline 12 & L. sinensis & 8.7 & 8.7 & 8.6 & 9.5 & 9.1 & 9.4 & 10.1 & 9.1 & 5.3 & 5.9 & 5.4 & - & - & 8.9 & 8.9 & 5.8 \\
\hline 13 & H. ligurriens & 9.7 & 9.0 & 9.0 & 10.0 & 9.7 & 9.9 & 10.5 & 10.0 & 6.1 & 8.6 & 7.5 & 6.1 & - & - & - & - \\
\hline 14 & H. pulchra & 9.3 & 9.0 & 8.4 & 9.9 & 9.4 & 9.7 & 10.2 & 9.6 & 6.1 & 8.3 & 7.2 & 5.9 & 1.1 & - & 4.2 & 6.1 \\
\hline 15 & H. infumata & 9.4 & 10.2 & 9.4 & 10.0 & 10.3 & 10.0 & 11.0 & 10.3 & 7.6 & 9.0 & 9.0 & 7.1 & 5.6 & 5.5 & - & 5.7 \\
\hline 16 & H. tumrasvini & 9.8 & 9.5 & 8.5 & 10.4 & 10.1 & 9.7 & 9.6 & 10.0 & 4.9 & 6.8 & 7.0 & 5.1 & 6.0 & 5.8 & 7.6 & - \\
\hline
\end{tabular}




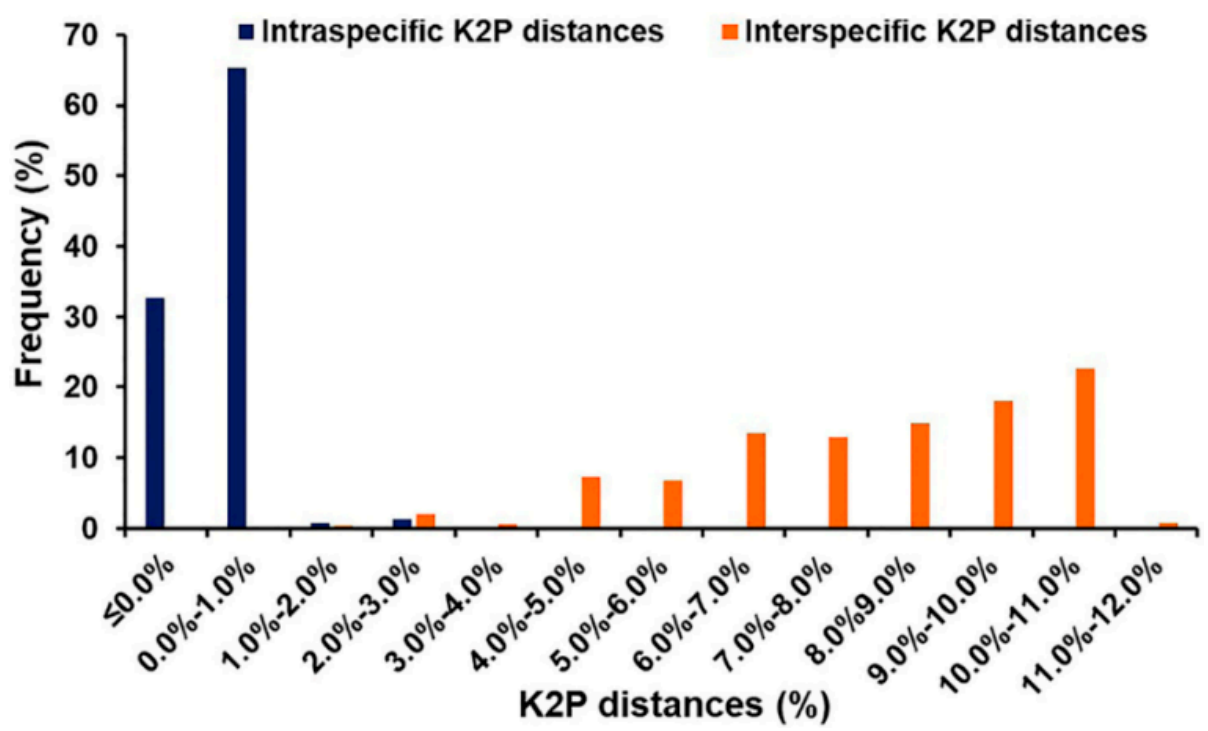

Figure 1. Frequency distribution of intra- and interspecific K2P distances among Thai blow flies based on 1247 bp of COI sequences.

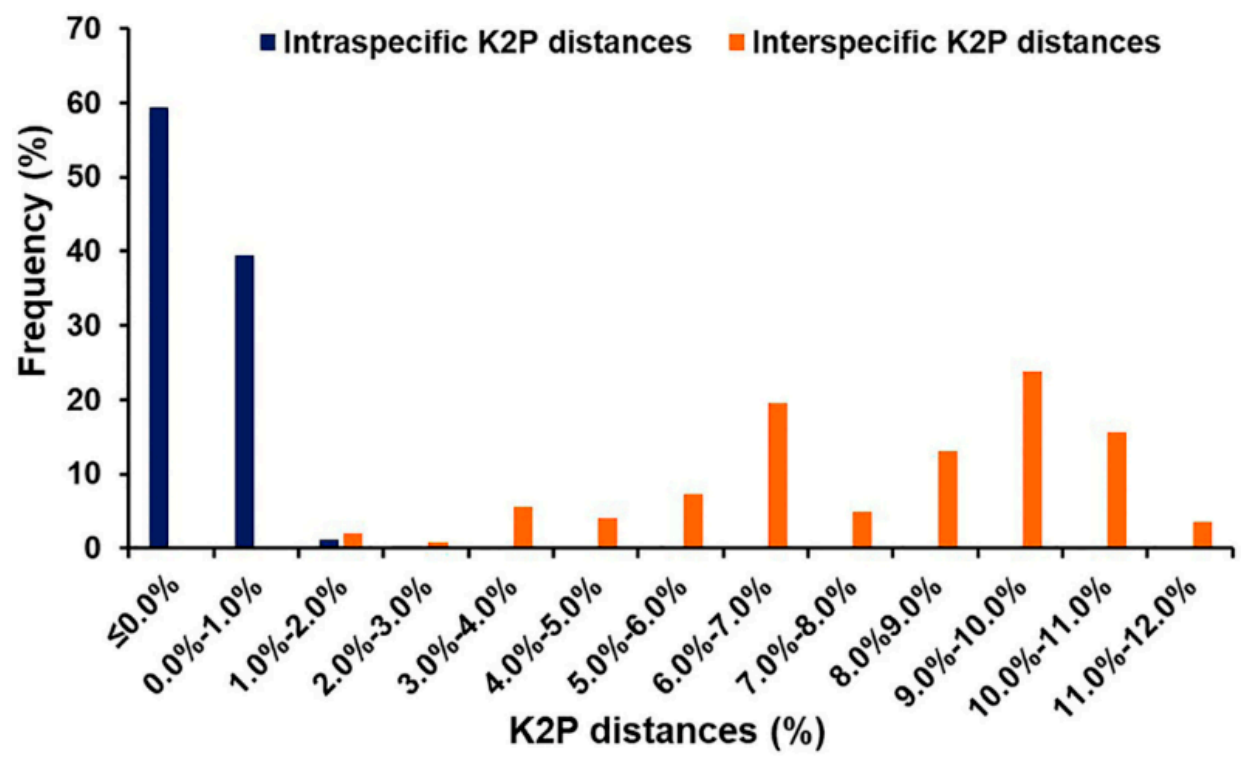

Figure 2. Frequency distribution of intra- and interspecific K2P distances among Thai blow flies based on 635 bp of COII sequences.

\subsection{Distance-Based Identification}

The percentage of correct identifications for $\mathrm{COI}$ and $\mathrm{COII}$ sequences of blow flies was similar (Table 4), revealing very high identification successes for BM (COI: $100 \%$; COII: $100 \%)$, BCM (COI: 98.24\%; COII: 98.01\%) and ASB (COI: 94.73\%; COII: 94.05\%) criteria. No incorrect identification was observed under the three criteria of both genes (Table 4). However, ambiguous identifications (COI: $3.50 \%$; COII: $3.96 \%$ ) were found only when the ASB criterion was used. The BCM and ASB criteria showed 1.75\% (COI: LC24-DL3, LPO31-1) and 1.98\% (COII: LPO31-1, LS33-1) of sequences with no matches closer than the calculated threshold (COI: 0.72\%; COII: 0.63\%) (Table 4). 
Table 4. Identification success based on Best Match (BM), Best Close Match (BCM) and All Species Barcodes (ASB) criteria for COI (1247 bp) and COII (635 bp) genes.

\begin{tabular}{lcc}
\hline \multicolumn{1}{c}{ Criteria } & COI & COII \\
\hline No. of sequences & 114 & 101 \\
\hline No. of species & 16 & 15 \\
\hline No. of sequences with closest match at 0\% difference & 57 & 80 \\
\hline No. of allospecific matches at 0\% difference & 0 & 0 \\
\hline Best Match (BM) & & \\
\hline - Correct identifications & $100.00 \%(114)$ & $100.00 \%(101)$ \\
- Ambiguous identifications & $0.00 \%(0)$ & $0.00 \%(0)$ \\
- Incorrect identifications & $0.00 \%(0)$ & $0.00 \%(0)$ \\
\hline Calculated threshold for Best Close Match and All Species Barcodes & $0.72 \%$ & $0.63 \%$ \\
\hline Best Close Match (BCM) & & \\
\hline - Correct identifications & $98.24 \%(112)$ & $98.01 \%(99)$ \\
- Ambiguous identifications & $0.00 \%(0)$ & $0.00 \%(0)$ \\
- Incorrect identifications & $0.00 \%(0)$ & $0.00 \%(0)$ \\
- No match closer than the calculated threshold & $1.75 \%(2)$ & $1.98 \%(2)$ \\
\hline All Species Barcodes (ASB) & & \\
\hline - Correct identifications & $94.73 \%(108)$ & $94.05 \%(95)$ \\
- Ambiguous identifications & $3.50 \%(4)$ & $3.96 \%(4)$ \\
- Incorrect identifications & $0.00 \%(0)$ & $0.00 \%(0)$ \\
- No match closer than the calculated threshold & $1.75 \%(2)$ & $1.98 \%(2)$ \\
\hline
\end{tabular}

\subsection{Tree-Based Identification}

The NJ trees of both COI and COII sequences were similar and clearly separated the blow flies from the house fly outgroup (Figures 3 and 4). For 90 representative COI sequences (1247 bp), all of 16 blow fly species showed a clear monophyletic cluster with high bootstrap support (90-99\%) (Figure 3). The blow flies were divided into two major clades consisting of subfamilies Chrysomyinae and Luciliinae, with bootstrap values of $92 \%$ and $99 \%$, respectively. Within Chrysomyinae, the genus Chrysomya was separated into two distinct clades; the major clade comprised six Chrysomya species (C. megacephala, C. pinguis, C. thanomthini, C. chani, C. bezziana and C. nigripes), while the minor one consisted of C. rufifacies and C. villeneuvi. Luciliinae was divided into two distinct clades comprising the Lucilia clade and the Hemipyrellia/Hypopygiopsis clade, both with high bootstrap support (99\%). Interestingly, $H$. tumrasvini was placed together with the clade of Lucilia, possibly establishing this clade as a sister to L. cuprina.

Regarding 67 representative COII sequences ( $635 \mathrm{bp}$ ), $15 \mathrm{blow}$ fly species (excluding the species of $H$. ligurriens of which NUMTs were retrieved) showed the monophyly of each species with high bootstrap support (97-100\%) (Figure 4). Two main distinct clades of the blow fly subfamilies, Chrysomyinae and Luciliinae, were also recovered using COII with bootstrap values of $79 \%$ and 93\%, respectively. Tree topology of Chrysomyinae was similar to that of COI. Within Luciliinae, the genera Hemipyrellia and Hypopygiopsis each formed a monophyletic group within the Lucilia clade with a low bootstrap value $(<50 \%)$. Similar to the COI tree, $H$. tumrasvini formed a sister clade near L. cuprina. 


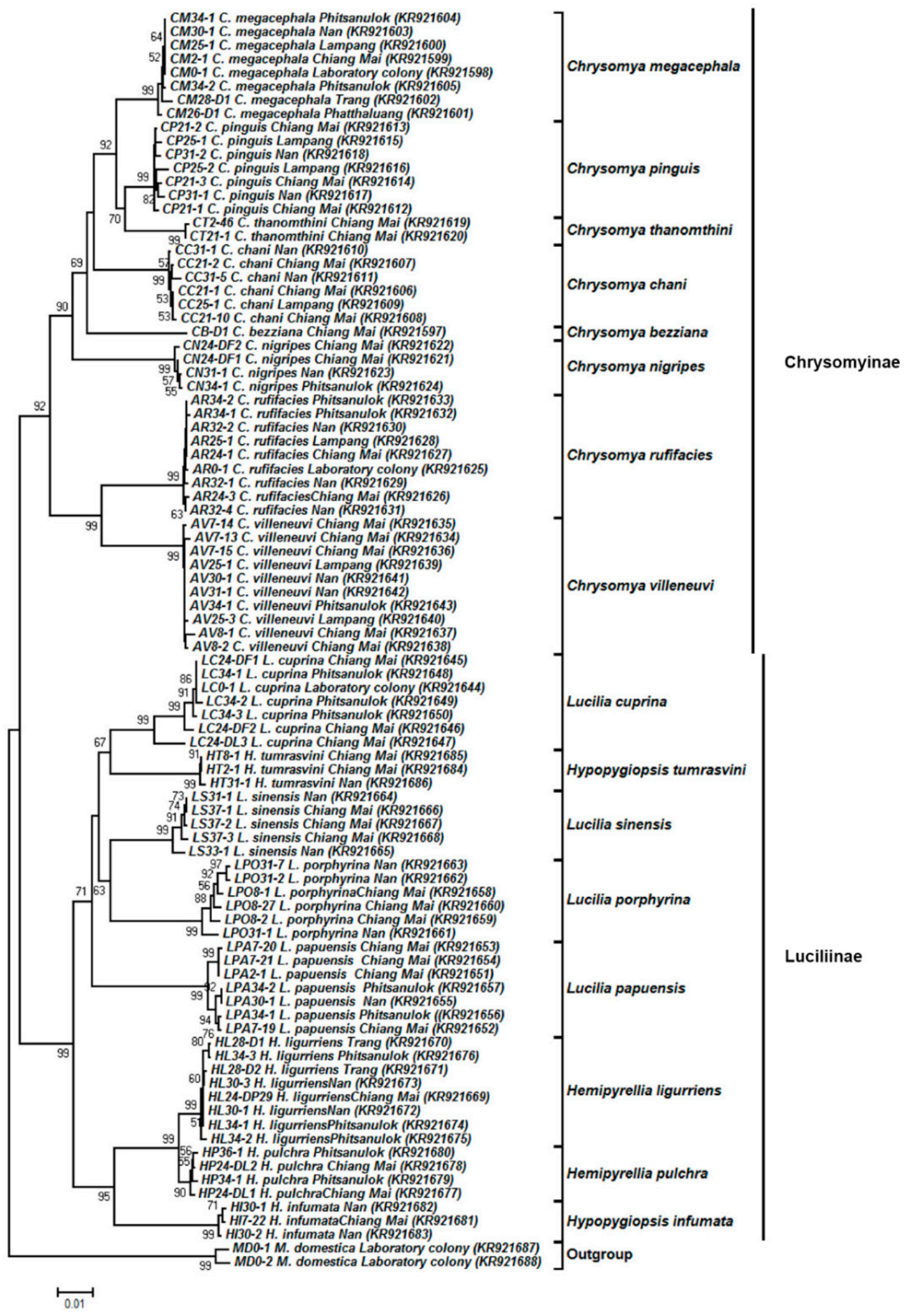

Figure 3. Neighbor-joining tree of COI sequences (1247 bp) based on the Kimura two-parameter model. Each specimen label includes the voucher code, species name, collection site, and accession number in parentheses, respectively. Bootstrap values $(>50 \%)$ are given near the appropriate node. The scale bar 0.01 indicates the evolutionary distance divergence. 


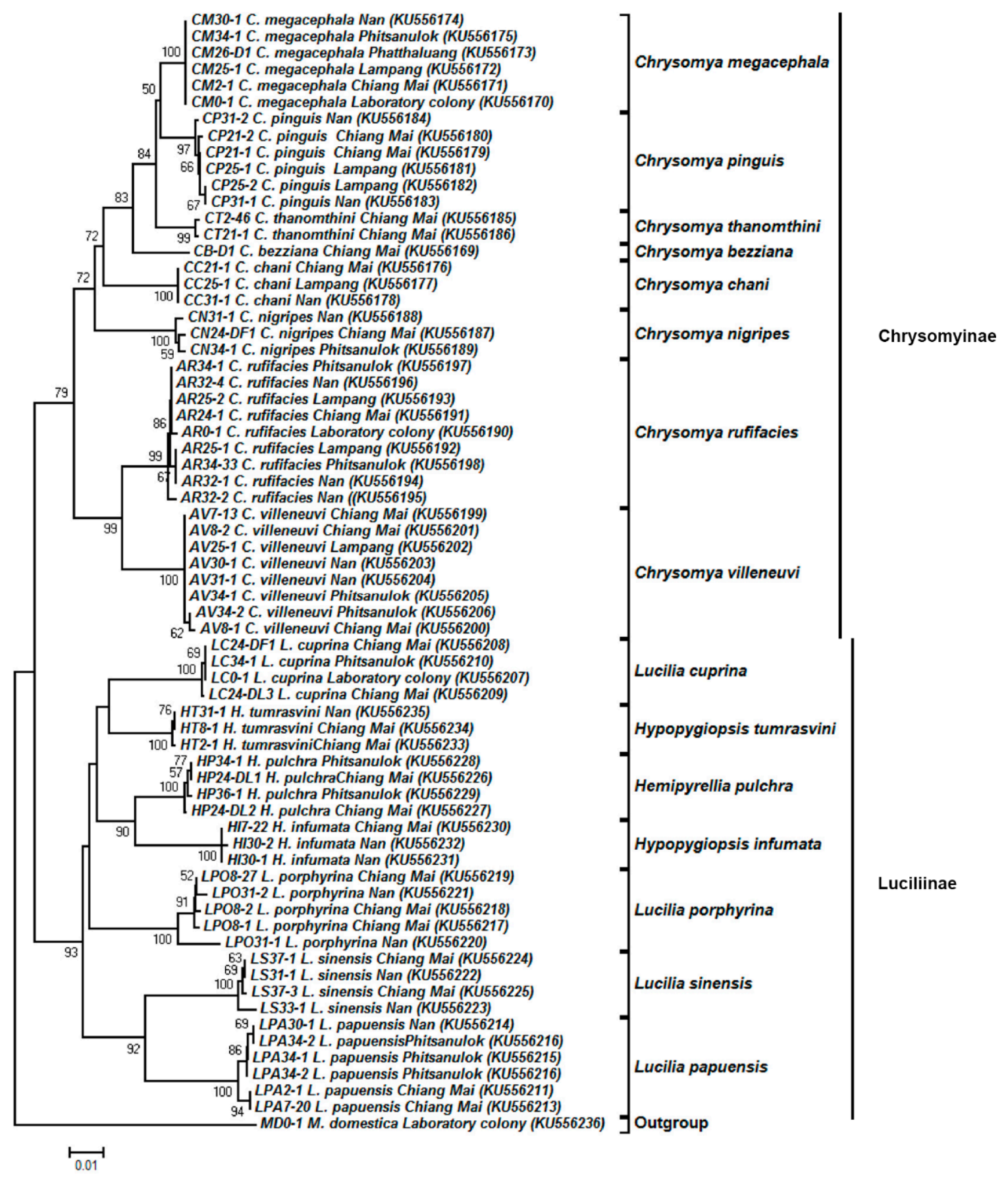

Figure 4. Neighbor-joining tree of COII sequences (635 bp) based on the Kimura two-parameter model. Each specimen label includes the voucher code, species name, collection site, and accession number in parentheses, respectively. Bootstrap values ( $>50 \%)$ are given near the appropriate node. The scale bar 0.01 indicates the evolutionary distance divergence.

\section{Discussion}

Although molecular-based identification has become widely accepted as an alternative to conventional morphology-based methods for identification in forensic entomology in Thailand, studies examining the genetic variation in targeted regions are scarce. Furthermore, a reference database of sequences from DNA barcode regions commonly used to identify the species of many forensically important flies from Thailand is still needed. Recently, our team assessed the use of partial sequences of nuclear $28 S$ rRNA (1000 bp) and mitochondrial COI ( $700 \mathrm{bp})$ genes in discriminating some Thai 
fly species. The study revealed that $C O I$ appeared to be more conclusive for species discrimination than $28 S$ rRNA, with no overlap between the intra- and interspecific distances [6]. In the present study, nearly full lengths of COI and COII sequences of 16 forensically relevant blow fly species in Thailand were evaluated for their efficacy in accurate species identification.

Although the universal COII primers used in this study have been known to work well for other blow flies [14,17,37] and flesh flies [38], the nuclear copies of mtDNA (NUMTs) were amplified instead of the authentic target mtDNA of all Thai H. ligurriens specimens. The NUMTs herein were detected by the presence of a premature stop codon, resulting in ambiguity into the COII alignment. Similarly, in a study of mitochondrial genome evolution of Chrysomya, most of the sequences of the typical insect trnQ gene was missing, and the partially duplicated $\operatorname{trn} Q$ was noted as a pseudogene [39]. Therefore, it is important to be aware of NUMTs when mtDNA is primarily used for phylogenetic studies. To avoid the co-amplification of NUMTs, several methods have been proposed, such as the use of mtDNA-rich tissue or fresh specimens, amplification of longer fragments, use of specific primers (e.g., taxon-specific primers), improving the PCR conditions, and using reverse transcriptase-coupled PCR (RT-PCR) [40-42]. Since NUMTs were only found in H. ligurriens when using the universal COII primers in this study, the use of specific primers should be considered in further genetic studies of COII of Thai H. ligurriens.

Intra- and interspecific distances are important for discriminating closely related species, because if the interspecific (congeneric) distances are less than the intraspecific distances, the taxonomic position indicated by the analyzed locus might be generally ambiguous and not be monophyletic [15,43]. However, the overlap between intra- and interspecific distances can occur even though each species is reciprocally monophyletic [43]. In this study, the COI data of most species had greater variability than those from the COII data. Most intraspecific distances of both COI and COII genes were less than $1 \%$, with the exception of L. cuprina (COI: $2.4 \%$ ) and L. porphyrina (COI: $1.1 \%$; COII: $1.9 \%$ ), while most interspecific distances were greater than $3 \%$, with the exception of four closely related species pairs (C. megacephala/C. pinguis (COI: 2.6\%; COII: $1.8 \%$ ), C. megacephala/C. thanomthini (COII: $2.2 \%$ ), C. pinguis/C. thanomthini (COI: $2.8 \%$; COII: $2.5 \%$ ), and H. ligurriens/H. pulchra (COI: $1.1 \%)$ ). Although some overlap between intra- and interspecific distances was observed in this study, the genetic diversity of COI and COII genes were sufficient for differentiating among 16 species of Thai blow flies; all species were reciprocally monophyletic on the NJ trees with high bootstrap support $(>90 \%)$, and identification success based on the three criteria-BM, BCM, and ASB-was very high $(>94 \%)$, with no incorrect identification. Therefore, COI and COII genes are effective markers for the identification of forensically important blow fly species in Thailand. Similar findings have been reported in previous studies in the blow flies in other countries $[7,8,14,16,17,44,45]$.

According to the study by Meier et al. [35], the three criteria-BM, BCM, and ASB - primarily rely on the sequence pairwise comparison. Therefore, some factors, such as sample size, species diversity, relatedness of species, geographical scale of sampling, and the use of GenBank sequences (which might include some misidentified sequences) in the analyzed dataset can affect the analysis $[6,35,43,46-48]$. Especially in the BCM and ASB criteria, genetic distances are needed for calculating the threshold value, therefore conspecific and congeneric sequences may act as biased data and influence the calculated value [35]. In this study, COI and COII genes showed an identification success of $100 \%$ for the BM criterion, while the BCM and ASB criteria showed lower identification success due to the presence of ambiguous identifications or no matches of queries in the dataset. The ambiguous identification under ASB criterion in this study was caused by a query that had only one conspecific match in the dataset (C. bezziana and C. thanomthini). In addition, "no match" under BCM and ASB criteria was caused by a query without a sequence match below the calculated threshold (COI: 0.72\%; COII: $0.63 \%$ ) (LC24-DL3 and LPO31-1 for COI, and LPO31-1 and LS33-1 for COII).

In this study, the NJ tree of individual markers showed that all specimens of the same species were correctly assigned to their respective species. The results indicated that COI and COII genes are suitable for identifying Thai blow flies, even between closely related species. When examining the phylogenetic relationships reconstructed using COI and COII genes, the placement of analyzed taxa 
within Chrysomyinae was similar while the placement of analyzed taxa within Luciliinae was fairly different (Figures 3 and 4). Within Luciliinae, the genera Hemipyrellia/Hypopygiopsis was embedded within the Lucilia clade based on the COII gene, whereas the genera Hemipyrellia/Hypopygiopsis was clearly separated from the Lucilia clade based on the COI gene. The incongruence of the tree topologies between $\mathrm{COI}$ and $\mathrm{COII}$ genes of blow flies observed in this study was not surprising because the phylogenetic placement of the blow flies often differed depending on gene of choice, gene length, species diversity, and phylogenetic tree building methods $[6,8,10,11,16,37,49,50]$.

The present study is the first to include H. tumrasvini. For both COI and COII, instead of being grouped with the congeneric species $H$. infumata, H. tumrasvini was recovered as a sister to L. cuprina even though their adult morphology is quite different. Considering genetic distance, L. cuprina and H. tumrasvini showed interspecific distances (COI: 4.9\%; COII: 4.8\%) lower than the intrageneric distances observed within Lucilia (COI: 5.3-7.8\%; COII: 5.7-9.4\%), resulting in H. tumrasvini forming as a sister species of L. cuprina. The previous phylogenetic analyses of Hypopygiopsis demonstrated that it grouped to either Lucilia or Hemipyrellia [6,11], suggesting that its relationship with Lucilia and Hemipyrellia is ambiguous. Therefore, the use of multiple genes in different loci as well as more species of these genera is needed to resolve their phylogenetic relationships.

\section{Conclusions}

Our results demonstrated that long COI and COII sequences can be used for accurate species identification of Thai blow flies. The obtained sequences of 16 forensically important blow fly species in this study act as a reliable DNA reference database for future research on forensic entomology not only in Thailand, but also other countries where these species exist. Although this study included the majority of forensically relevant blow fly species of Thailand, most of the specimens were obtained from the northern region. Therefore, future studies should be carried out using specimens from other geographical regions of Thailand for the development of a comprehensive reference database from all geographical regions and providing additional information on the genetic diversity.

Supplementary Materials: The following are available online at http://www.mdpi.com/2075-4450/9/4/159/s1, Figure S1: Map of Thailand showing the blow fly species collected in the sampling areas of six provinces, Table S1: Details of the Thai blow flies (Calliphoridae) and the house fly outgroup (Musidae) used in this study to obtain COI and COII sequences, Table S2: DNA polymorphism within species based on $1247 \mathrm{bp}$ of COI sequences and their GenBank accession numbers, and Table S3: DNA polymorphism within species based on $635 \mathrm{bp}$ of COII sequences and their GenBank accession numbers.

Author Contributions: Conceptualization, K.L.S. and K.S.; data curation, N.S.; formal analysis, N.S., B.K.Z., R.Z. and A.W.; funding acquisition, K.L.S., K.S. and T.C.; investigation, N.S. and A.W.; methodology, N.S., B.K.Z., R.Z. and A.W.; project administration, K.L.S. and K.S.; supervision, K.L.S., K.S. and A.W.; visualization, N.S. and J.A.; writing-original draft preparation, N.S. and A.W.; writing-review and editing, K.L.S., K.S., J.A. and A.W.

Funding: This research was financially supported by the Thailand Research Fund through the Royal Golden Jubilee Ph.D. Program (PHD/0118/2556 to K.L.S. and N.S.), International Research Network (IRN58W0003 to T.C. and K.L.S.), the Faculty of Medicine Research Fund, Chiang Mai University and "Diamond Research Grant" (PAR-2560-04663) of the Faculty of Medicine, Chiang Mai University.

Acknowledgments: We thank Chutharat Samerjai, Kwankamol Limsopatham, Sangob Sanit, Suttida Suwannayod, and Tunwadee Klong-klaew for helping in blow fly collection, and Hiromu Kurahashi for his advice on morphological identification of blow fly species.

Conflicts of Interest: The authors declare no conflict of interest.

\section{References}

1. Lane, R.P. An investigation into blowfly (Diptera: Calliphoridae) succession on corpses. J. Nat. Hist. 1975, 9, 581-588. [CrossRef]

2. Catts, E.P.; Goff, M.L. Forensic entomology in criminal investigations. Annu. Rev. Entomol. 1992, 37, $253-272$. [CrossRef] [PubMed]

3. Reibe, S.; Madea, B. How promptly do blowflies colonise fresh carcasses? A study comparing indoor with outdoor locations. Forensic Sci. Int. 2010, 195, 52-57. [CrossRef] [PubMed] 
4. Amendt, J.; Richards, C.S.; Campobasso, C.P.; Zehner, R.; Hall, M.J.R. Forensic entomology: Applications and limitations. Forensic Sci. Med. Pathol. 2011, 7, 379-392. [CrossRef] [PubMed]

5. Nelson, L.A.; Downton, M.; Wallman, J.F. Thermal attributes of Chrysomya species. Entomol. Exp. Appl. 2009, 133, 260-275. [CrossRef]

6. Zajac, B.K.; Sontigun, N.; Wannasan, A.; Verhoff, M.A.; Sukontason, K.; Amendt, J.; Zehner, R. Application of DNA barcoding for identifying forensically relevant Diptera from northern Thailand. Parasitol. Res. 2016, 115, 2307-2320. [CrossRef] [PubMed]

7. Bharti, M.; Singh, B. DNA-based identification of forensically important blow flies (Diptera: Calliphoridae) from India. J. Med. Entomol. 2017, 54, 1151-1156. [CrossRef] [PubMed]

8. $\quad$ Meng, F.; Ren, L.; Wang, Z.; Deng, J.; Guo, Y.; Chen, C.; Finkelbergs, D.; Cai, J. Identification of forensically important blow flies (Diptera: Calliphoridae) in China based on COI. J. Med. Entomol. 2017, 54, 1193-1200. [CrossRef] [PubMed]

9. McDonagh, L.M.; Stevens, J.R. The molecular systematics of blowflies and screwworm flies (Diptera: Calliphoridae) using 28S $r R N A, C O X 1$ and EF-1 $\alpha$ : Insights into the evolution of dipteran parasitism. Parsitology 2011, 138, 1760-1777. [CrossRef] [PubMed]

10. Singh, B.; Kurahashi, H.; Wells, J.D. Molecular phylogeny of the blowfly genus Chrysomya. Med. Vet. Entomol. 2011, 25, 126-134. [CrossRef] [PubMed]

11. Williams, K.A.; Lamb, J.; Villet, M.H. Phylogenetic radiation of the greenbottle flies (Diptera, Calliphoridae, Luciliinae). Zookeys 2016, 586, 59-86. [CrossRef] [PubMed]

12. Saccone, C.; De Giorgi, C.; Gissi, C.; Pesole, G.; Reyes, A. Evolutionary genomics in Metazoa: The mitochondrial DNA as a model system. Gene 1999, 238, 195-209. [CrossRef]

13. Sperling, F.A.; Anderson, G.S.; Hickey, D.A. A DNA-based approach to the identification of insect species used for postmortem interval estimation. J. Forensic Sci. 1994, 39, 418-427. [CrossRef] [PubMed]

14. Wallman, J.F.; Donnellan, S.C. The utility of mitochondrial DNA sequences for the identification of forensically important blowflies (Diptera: Calliphoridae) in southeastern Australia. Forensic Sci. Int. 2001, 120, 60-67. [CrossRef]

15. Wells, J.D.; Sperling, F.A. DNA-based identification of forensically important Chrysomyinae (Diptera: Calliphoridae). Forensic Sci. Int. 2001, 120, 110-115. [CrossRef]

16. Nelson, L.A.; Wallman, J.F.; Dowton, M. Using COI barcodes to identify forensically and medically important blowflies. Med. Vet. Entomol. 2007, 21, 44-52. [CrossRef] [PubMed]

17. Ying, B.W.; Liu, T.T.; Fan, H.; Wei, D.; Wen, F.Q.; Bai, P.; Huang, J.; Hou, Y.P. The application of mitochondrial DNA cytochrome oxidase II gene for the identification of forensically important blowflies in western China. Am. J. Forensic Med. Pathol. 2007, 28, 308-313. [CrossRef] [PubMed]

18. Kurahashi, H.; Bunchu, N. The blow flies recorded from Thailand, with the description of a new species of Isomyia Walker (Diptera, Calliphoridae). Jpn. J. Syst. Entomol. 2011, 17, 237-278.

19. Sukontason, K.; Sukontason, K.L.; Piangjai, S.; Tippanun, J.; Lertthamnongtham, S.; Vogtsberger, R.C.; Olson, J.K. Survey of forensically-relevant fly species in Chiang Mai, northern Thailand. J. Vector Ecol. 2003, 28, 135-138. [PubMed]

20. Bunchu, N.; Sukontason, K.; Sanit, S.; Chidburee, P.; Kurahashi, H.; Sukontason, K.L. Occurrence of blow fly species (Diptera: Calliphoridae) in Phitsanulok province, northern Thailand. Trop. Biomed. 2012, 29, 532-543. [PubMed]

21. Moophayak, K.; Klong-klaew, T.; Sukontason, K.; Kurahashi, H.; Tomberlin, J.K.; Sukontason, K.L. Species composition of carrion blow flies in northern Thailand: Altitude appraisal. Rev. Inst. Med. Trop. Sao Paulo 2014, 56, 179-182. [CrossRef] [PubMed]

22. Klong-klaew, T.; Sontigun, N.; Sanit, S.; Samerjai, C.; Sukontason, K.; Kurahashi, H.; Koehler, P.G.; Pereira, R.M.; Limsopatham, K.; Suwannayod, S.; et al. Field evaluation of a semi-automatic funnel trap targeted the medically important non-biting flies. Acta Trop. 2017, 176, 68-77. [CrossRef] [PubMed]

23. Sukontason, K.; Narongchai, P.; Kanchai, C.; Vichairat, K.; Sribanditmongkol, P.; Bhoopat, T.; Kurahashi, H.; Chockjamsai, M.; Piangjai, S.; Bunchu, N.; et al. Forensic entomology cases in Thailand: A review of cases from 2000 to 2006. Parasitol. Res. 2007, 101, 1417-1423. [CrossRef] [PubMed] 
24. Monum, T.; Sukontason, K.L.; Sribanditmongkol, P.; Sukontason, K.; Samerjai, C.; Limsopatham, K.; Suwannayod, S.; Klong-klaew, T.; Wannasan, A. Forensically important blow flies Chrysomya pinguis, C. villeneuvi, and Lucilia porphyrina (Diptera: Calliphoridae) in a case of human remains in Thailand. Korean J. Parasitol. 2017, 55, 71-76. [CrossRef] [PubMed]

25. Sukontason, K.L.; Bhoopat, T.; Wannasan, A.; Sontigun, N.; Sanit, S.; Amendt, J.; Samerjai, C.; Sukontason, K. Chrysomya chani Kurahashi (Diptera: Calliphoridae), a blow fly species of forensic importance: Morphological characters of the third larval instar and a case report from Thailand. Forensic Sci. Res. 2018, 3, 83-93. [CrossRef]

26. Sukontason, K.; Sukontason, K.L.; Piangjai, S.; Boonchu, N.; Kurahashi, H.; Hope, M.; Olson, J.K. Identification of forensically important fly eggs using a potassium permanganate staining technique. Micron 2004, 35, 391-395. [CrossRef] [PubMed]

27. Sukontason, K.; Sukontason, K.L.; Ngern-klun, R.; Sripakdee, D.; Piangjai, S. Differentiation of the third instar of forensically important fly species in Thailand. Ann. Entomol. Soc. Am. 2004, 97, 1069-1075. [CrossRef]

28. Preativatanyou, K.; Sirisup, N.; Payungporn, S.; Poovorawan, Y.; Thavara, U.; Tawatsin, A.; Sungpradit, S.; Siriyasatien, P. Mitochondrial DNA-based identification of some forensically important blowflies in Thailand. Forensic Sci. Int. 2010, 202, 97-101. [CrossRef] [PubMed]

29. Simon, C.; Frati, F.; Beckenbach, A.; Crespi, B.; Liu, H.; Flook, P. Evolution, weighting, and phylogenetic utility of mitochondrial gene sequences and a compilation of conserved polymerase chain reaction primers. Ann. Entomol. Soc. Am. 1994, 87, 651-701. [CrossRef]

30. Bogdanowicz, S.M.; Wallner, W.E.; Bell, J.; Odell, T.M.; Harrison, R.G. Asian gypsy moths (Lepidoptera: Lymantriidae) in North America: Evidence from molecular data. Ann. Entomol. Soc. Am. 1993, 86, 710-715. [CrossRef]

31. Hall, T.A. Bioedit: A user-friendly biological sequence alignment editor and analysis program for Windows 95/98/NT. Nucleic Acids Symp. Ser. 1999, 41, 95-98.

32. Librado, P.; Rozas, J. Dnasp v5: A software for comprehensive analysis of DNA polymorphism data. Bioinformatics 2009, 25, 1451-1452. [CrossRef] [PubMed]

33. Kimura, M. A simple method for estimating evolutionary rates of base substitutions through comparative studies of nucleotide sequences. J. Mol. Evol. 1980, 16, 111-120. [CrossRef] [PubMed]

34. Tamura, K.; Stecher, G.; Peterson, D.; Filipski, A.; Kumar, S. MEGA6: Molecular Evolutionary Genetics Analysis version 6. Mol. Biol. Evol. 2013, 30, 2725-2729. [CrossRef] [PubMed]

35. Meier, R.; Shiyang, K.; Vaidya, G.; Ng, P.K.L. DNA barcoding and taxonomy in Diptera: A tale of high intraspecific variability and low identification success. Syst. Biol. 2006, 55, 715-728. [CrossRef] [PubMed]

36. Hebert, P.D.N.; Cywinska, A.; Ball, S.L.; deWaard, J.R. Biological identifications through DNA barcodes. Proc. R. Soc. Lond. B 2003, 270, 313-321. [CrossRef] [PubMed]

37. Wallman, J.F.; Leys, R.; Hogendoorn, K. Molecular systematics of Australian carrion-breeding blowflies (Diptera: Calliphoridae) based on mitochondrial DNA. Invertebr. Syst. 2005, 19, 1-15. [CrossRef]

38. Guo, Y.D.; Cai, J.F.; Xiong, F.; Wang, H.J.; Wen, J.F.; Li, J.B.; Chen, Y.Q. The utility of mitochondrial DNA fragments for genetic identification of forensically important sarcophagid flies (Diptera: Sarcophagidae) in China. Trop. Biomed. 2012, 29, 51-60. [PubMed]

39. Lessinger, A.C.; Junqueira, A.C.M.; Conte, F.F.; Azeredo-Espin, A.M.L. Analysis of a conserved duplicated tRNA gene in the mitochondrial genome of blow flies. Gene 2004, 339, 1-6. [CrossRef] [PubMed]

40. Collura, R.V.; Auerbach, M.R.; Stewart, C.B. A quick, direct method that can differentiate expressed mitochondrial genes from their nuclear pseudogenes. Curr. Biol. 1996, 6, 1337-1339. [CrossRef]

41. Song, H.; Buhay, J.E.; Whiting, M.F.; Crandall, K.A. Many species in one: DNA barcoding overestimates the number of species when nuclear mitochondrial pseudogenes are coamplified. Proc. Natl. Acad. Sci. USA 2008, 105, 13486-13491. [CrossRef] [PubMed]

42. Leite, L.A.R. Mitochondrial pseudogenes in insect DNA barcoding: Differing points of view on the same issue. Biota Neotrop. 2012, 12, 301-308. [CrossRef]

43. Meyer, C.P.; Paulay, G. DNA barcoding: Error rates based on comprehensive sampling. PLoS Biol. 2005, 3, e422. [CrossRef] [PubMed]

44. Park, S.H.; Zhang, Y.; Piao, H.; Yu, D.H.; Jeong, H.J.; Yoo, G.Y.; Chung, U.; Jo, T.H.; Hwang, J.J. Use of cytochrome c oxidase subunit I (COI) nucleotide sequences for identification of the Korean Luciliinae fly species (Diptera: Calliphoridae) in forensic investigations. J. Korean Med. Sci. 2009, 24, 1058-1063. [CrossRef] [PubMed] 
45. Salem, A.M.; Adham, F.K.; Picard, C.J. Survey of the genetic diversity of forensically important Chrysomya (Diptera: Calliphoridae) from Egypt. J. Med. Entomol. 2015, 52, 320-328. [CrossRef] [PubMed]

46. Wells, J.D.; Stevens, J.R. Application of DNA-based methods in forensic entomology. Annu. Rev. Entomol. 2008, 53, 103-120. [CrossRef] [PubMed]

47. Virgilio, M.; Jordaens, K.; Breman, F.C.; Backeljau, T.; De Meyer, M. Identifying insects with incomplete DNA barcode libraries, African fruit flies (Diptera: Tephritidae) as a test case. PLoS ONE 2012, 7, e31581. [CrossRef] [PubMed]

48. Sonet, G.; Jordaens, K.; Braet, Y.; Bourguignon, L.; Dupont, E.; Backeljau, T.; De Meyer, M.; Desmyter, S. Utility of GenBank and the Barcode of Life Data Systems (BOLD) for the identification of forensically important Diptera from Belgium and France. Zookeys 2013, 365, 307-328. [CrossRef] [PubMed]

49. Aly, S.M. Reliability of long vs short COI markers in identification of forensically important flies. Croat. Med. J. 2014, 55, 19-26. [CrossRef] [PubMed]

50. GilArriortua, M.; Saloña Bordas, M.I.; Köhnemann, S.; Pfeiffer, H.; de Pancorbo, M.M. Molecular differentiation of Central European blowfly species (Diptera, Calliphoridae) using mitochondrial and nuclear genetic markers. Forensic Sci. Int. 2014, 242, 274-282. [CrossRef] [PubMed]

(C) 2018 by the authors. Licensee MDPI, Basel, Switzerland. This article is an open access article distributed under the terms and conditions of the Creative Commons Attribution (CC BY) license (http:/ / creativecommons.org/licenses/by/4.0/). 